\title{
Online Model for Teaching and Learning the Specialized Translation
}

\author{
Nataliya Gavrilenko ${ }^{1 *}$ \\ ${ }^{1}$ Foreign Languages Department of Engineering Academy, Peoples' Friendship University of Russia, Moscow, RUSSIA
}

Received 21 March 2017 • Revised 30 August 2017 • Accepted 15 September 2017

\begin{abstract}
The relevance of the research problem is driven by the modern discourse in translation pedagogy. Our understanding of the network enables to find a new way in modelling translation process in the context of modern communications flow, professional groups, databases, interaction technologies for translation companies and clients, project managers and translators etc. The online model for teaching and learning translation is not limited to communication networks. Its main linking node is a social subject - the learner. Such social network's feature as a cell-based structure makes it possible to present theoretical and practical material in the form of modules that include challenges, solution options, necessary internal and external resources, learning activities and ways to check the achievements. The practical value is that the online model for teaching and learning translation will help the students to learn certain modular blocks of the translation model by using structured and unstructured communication channels.
\end{abstract}

Keywords: specialized translation, translational-oriented educational environment, professional competences, translation engine, network communication

\section{INTRODUCTION}

The translator's activity was significantly changed over the past decade (Deng, 2016; Gümüş, 2017; Robinson, Olvera Lobo, \& Gutiérrez-Artacho, 2017). He is not asked to provide a paper version or a floppy disk with a translated text on it; he is not asked to send the translation file by e-mail. His activities are in an online environment (Bestué \& Orozco, 2016; Choi, Kim, Ullah, \& Kang, 2016): translator can get a PDF file with Excel tables and footnotes at the bottom of the page in a Word document. He will have to combine all this information in a translated text and to post it on the website in a specified format (Munday, 2016).

It is pertinent to point out that there is a continuous diversification of special fields (software localization, project management, knowledge management and information management, web content management, the ability to use multimedia and technical equipment, etc.) (Bassnett, 2013; House, 2014; Roh, 2015; Wang, Maeda, \& Takahashi, 2014). These changes require new approaches to modelling the translator's activity and preparation. This is particularly evident in the case of specialized translation (Faber, 2012; Shiyab, 2017; Yang, Guo, \& Yu, 2016). It is regarded as a "marriage of analog and digital approaches" at the junction of Sciences and Arts (Froeliger, 2013).

One can note that Russian translation studies have been based on the linguistic approach to modeling the translator's activity for a long time (Gavrilenko, 2016; Kujamäki \& Footitt, 2016; Venuti, 2012). The gradual shift from analyzing the source text and the target text to identity analysis of the translation subject has greatly expanded the understanding of this professional activity. Cognitive science development entails the proposition of a complex translation model as a verbal-cogitative process (translator's knowledge in combination with the semantic potential of a source text), and its substantiation by an experiment (Chesterman, 2016).

It should be noted that current social network models are typically divided into two main categories: social network formation model and innovation diffusion model (Davydova, Dorozhkin, Fedorov, \& Konovalova, 2016). Teaching model for learning specialized translation may be classified as a model of professional training experience

(C) 2018 by the authors; licensee Modestum Ltd., UK. This article is an open access article distributed under the terms and conditions of the Creative Commons Attribution License (http://creativecommons.org/licenses/by/4.0/). \gavrilenko.nta@gmail.com (*Correspondence) 


\section{Contribution of this paper to the literature}

- Suggested translation-based educational network allows to concentrate the accumulated knowledge in the field of translation and translation studies, current teaching methods for different interpretation trades and to find partners for joint research and training, to form groups of professional interests to improve translation skills.

- The proposed ayatem of interactive learning allows students to learn other culture by communicating with its representatives, to discuss translation difficulties with native speakers, etc.

- We have consistently correlated the elements of translation competence with determined challenges in order to represent the training modules in a form of an online model. Thus, each training module that we have contains a translational challenge and professional knowledge, skills and traits necessary for its solution.

distribution (Baker \& Maier, 2011). In early 2000, we have received a Web 2.0 development, which allowed users to create and distribute different types of content and to form social networks. Social networks became to have not only communication functions, but also the teaching-learning functions ( $\mathrm{O}^{\prime}$ reilly, 2005).

Educational platforms are structures for professional groups to share information and coordinate research and teaching activities, own approaches and other actions, aimed at gaining required competencies. Such platforms in the field of education bring together the representatives of educational institutions that are communicating with each other, exchanging views on education, contributing to a creation of new educational platforms and to a revision of concepts and roles of a tutor and a student (Martín-Blas \& Serrano-Fernández, 2009). For example, there are educational platform focused on the teaching and learning foreign languages: Babel (11 languages, over a million users), Busuu (7 languages and more than 9 million users), Livemocha (35 languages and more than 9 million users) (Garcia, 2013).

Currently, there is no single definition for an Educational Platform. This term is often used in relation to online tutorials, video lectures, presentations, tests, etc. (S. Kim, Kim, Park, \& Oh, 2016; Padilla-Zea, Medina, Vela, Paderewski, \& Collazos, 2017). In this case, we adhere to the definition of online model for teaching and learning translation as an interaction between teachers, translators and students in the context of information technologies, contributing to the creation of appropriate curriculum and an optimal environment for learning, self-study and improvement in the field of translation. Thus, we have a new environment for translator's activity and preparation, which changes the vision of space and time. Presently, teaching and learning translation is impossible out of touch with the community of professional translators, which exists in the context of communications flow, professional groups and sites, databases, interaction technologies for translation companies and clients, project managers and translators (O'Hagan, 2011; Pérez-González \& Susam-Saraeva, 2012). These flows should be included in the educational context for preparing translators within a professional context.

\section{METHODOLOGICAL FRAMEWORK}

\section{Network Analysis and Translator's Activity}

Synergetic approach allows considering both physical and social phenomena, studying the self-organization processes of various systems with linguistic and cultural factors, allowing visualizing their links more clearly while translating (Remkhe, Nefedova, \& Gillespie, 2016). Moreover, this approach is regarded as «not just dynamic, but as a self-developing and self-organizing system» (Kushnina \& Pylaeva, 2014). Thus, we can classify it as a synergistic system and examine it within the synergetic linguistics.

The network approach, considering modern society as a network society, is one of synergistic approach manifestations. In this case, social structures of society are in the center of network research. Sociologists consider the social network as a union of social terms - social actors and their relationships. The network phenomenon is often explained by the means of a mathematical notion (graph), which may be represented as a number of nodes, connected by edges. The Social Network is a group of nodes: social actors and the relationships between them (social interaction) for resource exchange (Castells, 2003).

One can note that translator's activity is an open dynamic system, which includes many nodes-graphs with edges-links between various elements. For example, the translator himself is linked to the client and to the social environment with a target language. Specialized text is understood based on the translation analysis: communication features in a particular professional environment and social institution, which is difficult to consider out of touch with respective organizations, higher education institutions, traditions, communication ethics etc. (Kim, 2014). Communicative situation, represented by such «nodes» as the «who, where, when, for what purpose, for whom?» is a base for the source text etc. Text translation must be with due account for target language and for features of a particular reader, his occupation, the communicative situation, in which the text will be used. 
Each of these elements is related to a number of other determining factors. Online translation model is a combination of these links.

\section{RESULTS AND DISCUSSION}

\section{Online Model for Teaching and Learning the Specialized Translation}

Translation environment for related teachers is not linear. Teacher's professional development depends on various factors: environment, personal beliefs, experiences (teaching and translation), practice etc. (Dogan, Pringle, \& Mesa, 2016). These factors rise in creating and implementing the pedagogical teaching models, as well as in the process of consideration, which allows the teacher to structure and generalize the pedagogical situation, to modify and adapt it to different audiences (Bernardini, 2016).

How, who and what should be combined in the educational context? Knowledge and information can be imparted through structured and unstructured channels. Such feature of a network communication as a multichannel and cell-based structure is a significant factor in creating this context, covering a significant space. This educational platform is not limited to communication networks. Our analysis of the network actors that are able to contribute to translator's preparation in a certain way has allowed identifying four information channels.

The first channel - universities, high educational institutions training translators. There are a lot of translation researchers, who accumulate the latest achievements in the field of professional translation and translation studies. These organizations distribute the standards of professional behavior and information about the best material, contributing to a formation of a database involving scientific and practical publications, translation resources, addresses and resumes of different teachers, their service assess terms, etc. Teachers in the field of translation help the students to develop their own styles of learning to achieve the set goals (Biel, 2011).

Currently, the growth of scientific knowledge in these areas is much lower than the increase of researchers. The major part of scientists is required to «hold» the current level of knowledge and education. The necessity to consider translator's activities from the integrative point leads to the process of narrowing the range of issues under consideration. Thus, something important may be missed.

By the way, graduates of translator-training programs in Turkey were asked how well academic training prepared them for professional work. Thus, slightly over half of the respondents $(51.7 \%)$ agreed that the academic training had prepared them fairly well. $12.4 \%$ affirmed that the training prepared them extremely well for professional work, whereas $34.8 \%$ of the respondents said that the academic training had provided only basic preparation (Gümüş, 2017).

The second channel - knowledge and strategies for organizational and professional solutions can be gained in professional associations, associations of translators, translation-related websites, from professional translators and free-lancers. This channel may involve specific issues on learning translation, online training programs, developed by translation and interpreting companies that are happy to consult those, who are willing to speak about own skills and demonstrate them in practice, etc.

The third channel - information can be gained by means of a network involving translation and interpreting companies and organizations that are often using translation services. Such networks are used to find solutions on different problems, provided by clients, consumers and members of translation and interpreting companies. They relay information about innovations in the administrative law, about technological innovations, terminological databases, new translation engines etc., as they are important in translator's activity.

The fourth channel - a group of network managers is necessary to serve the network, as they introduce devices and technologies that help to teach and learn specialized translation, as well as provide the assess to available resources and their network security.

\section{Module-Based Translation System as a Base of an Online Model for Teaching and Learning Translation}

Such network's feature as a cell-based structure makes it possible to present the learning material in the form of modules. Module technology is widely used in modern high educational institutions. Experts in the field of module education allocate its various elements: module as a package of learning material, as a training unit, as an information block, as a set of academic disciplines, as a program for professional training, etc. (Gulati, 2008; Zaidan \& Callison-Burch, 2011). Module allows preserving the integrity of learning material and its assimilation in structural elements. For example, there is developed a PCTD (personal creative thinking development) system that was implemented in a number of universities in the field of engineering education. It is based on module learning. Module is a part of educational program that synthesizes transdisciplinary issues and problems. 
Table 1. Translation competencies

\begin{tabular}{ll}
\hline $\begin{array}{l}\text { Intercultural } \\
\text { communicative } \\
\text { competence }\end{array}$ & $\begin{array}{l}\text { Readiness and ability (in accordance with the professional speech culture) to understand the } \\
\text { statements in foreign language and to re-create them in Russian orally or in written for on the basis } \\
\text { of understood meaning }\end{array}$ \\
\hline Special competence & $\begin{array}{l}\text { Readiness and ability to translate at a high level, possession of appropriate knowledge and skills and } \\
\text { the ability to plan further development }\end{array}$ \\
\hline Social competence & $\begin{array}{l}\text { Level of joint professional activity, specific communication methods, social responsibility for } \\
\text { performance etc. }\end{array}$ \\
\hline Personal competence & Possession of appropriate personal traits that are important in translation activity \\
\hline
\end{tabular}

We have analyzed all the elements of translator's professional competency and determined the sequence of system's objectives in order to present a module system for teaching and learning translation.

Competence-based approach is one of important approaches in modern education (Göpferich, 2009). Unfortunately, translation studies have no common approach in considering the actual translation competence and in determining its elements. Literature analysis on translation studies shows the complexity, diversity and double meaning of interpreting this concept, its structure and determined competences. The lack of a common approach in considering the composition of translator's professional competence has determined the theoretical substantiation of determining major translation competencies - generalized competencies that ensure normal human life in society, in our case, in professional translational environment.

Analysis of elements, allocated in the translation competency, allowed us to determine four major competencies (Table 1).

Each of major translator's competence has a number of sub-competences with an open structure that could be changed during further development of important aspects.

It is worth noting that the universally recognized professionally-oriented model of competences was proposed by the EMT expert group (established by the Directorate-General for Translation, European Commission). The following model is regarded as a guideline for Master's level translation programmes and includes translation service provision competence, language competence, intercultural competence, information mining competence, technological competence and thematic competence (Gambier, 2009).

Competence-based approach in teaching translation involves the interaction of personality and activity elements. Any professional activity is carried out in a specific social context; therefore, activity approach to teaching states that translation competence is possible to form gradually in solving translation challenges (Martínez Melis \& Hurtado Albir, 2001). For example, task-specific approach is required to use in learning a foreign language with information technologies, as it highlights the macro- and micro-challenges. Solutions for macro-challenges have to be made in a social context by creating a background for interaction with other participants in the educational process, fitting it in the context of a real professional communication. Solutions for micro-tasks are made by carrying out necessary actions. The process of finding these solutions is more independent and private (Grosbois, 2012; J. H. Kim, 2014).

Translator's activity analysis with specialized texts allowed us to present a sequence of challenges. An experienced translator may not face certain challenges. However, this algorithm of professional activities helps to come with learning materials and to propose appropriate methods and techniques for translation competence formation.

Determined challenges were distributed in accordance with the following learning stages:

- professionally-orienting stage - job hunting, receiving a text for translation from the employer, preparations;

- analytical stage - foreign text comprehension and interpretation (information-reference search and translation analysis), translation strategy development;

- constructing stage - terminology search, matching and translation on the basis of foreign text;

- proofreading stage - correction, editing and turning in a paper for the client.

We have consistently correlated the elements of translation competence with determined challenges in order to represent the training modules in a form of an online model. Thus, the each training module that we have contains a translational challenge and professional knowledge, skills and traits necessary for its solution.

An online model for teaching and learning the specialized translation using information technologies is an example of such a module technology (Figure 1). 
Each training module of developed system includes the following elements:

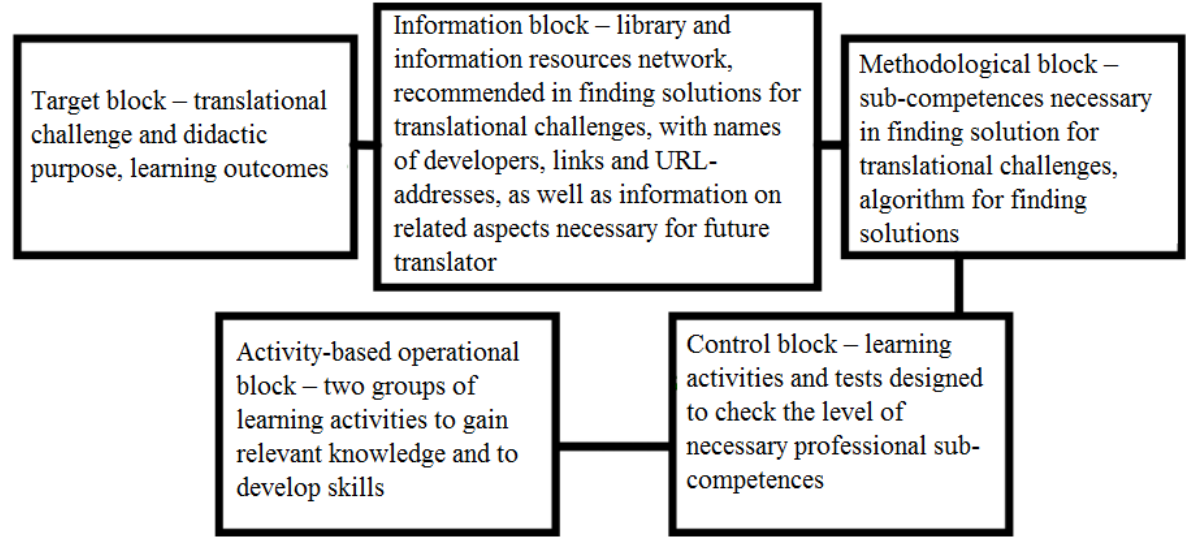

Figure 1. Elements of training module for developed translation system

Thus, each training module includes a specific macro-challenge, options for its solution, information resources to solve it, necessary sub-competences, bank of learning activities, options to check the level of translation competence, student-to-student, student-to-translator and student-to-teacher communication abilities. This interactive learning allows students to learn other culture by communicating with its representatives, to discuss translation difficulties with native speakers, etc. Motivation is known to be higher through this communication everyone can help and get help, such abilities as interaction, teamwork, etc. are developed. In contrast, the ability of independent work is formed due to working with micro-challenges. Furthermore, educational practice within the implementation of models of educational networks proves that the effect of joint activity is always higher than individual efforts due to the increase in the cooperation potential, expansion of relationships, and specific intellectual products (Davydova et al., 2016).

\section{CONCLUSION}

To sum up, traditional linear system for teaching translation (sequential learning of certain topics, techniques and methods of translation, translation instruments) makes it difficult to introduce and to form a full image of professional activity. In a network-learning environment, new theoretical and practical material is presented in modules and distributed throughout the whole course.

In this case, the presentation sequence of learning material in the net is not important. On the contrary, it is how it makes the students to look for the right information, categorize and use it. Such an online model can have many interconnected modules that provide a general idea of translation as a profession. There is special information on how to generate the necessary abilities and skills, how to use different translation engines, to go to different professional translation communities, databases etc. The Network remains a source for gaining knowledge, but the actions of the students are no less important, as well as their ability to gain knowledge independently, to find and to choose the way to generate abilities, etc.

Suggested translation-based educational network allows to concentrate the accumulated knowledge in the field of translation and translation studies, current teaching methods for different interpretation trades and to find partners for joint research and training, to form groups of professional interests to improve translation skills. Translation-based educational network allows regularly enriching and improving the knowledge base and offering new technologies; it is easy to find information by taking into account the diversity of interpretation trades in this fast-growing profession and by selecting the learning strategies that meet the learner's personality.

\section{REFERENCES}

Baker, M., \& Maier, C. (2011). Ethics in interpreter \& translator training: Critical perspectives. The Interpreter and Translator Trainer, 5(1), 1-14. https:/ / doi.org/10.1080/13556509.2011.10798809

Bassnett, S. (2013). Translation Studies. Psychology Press.

Bernardini, S. (2016). Discovery learning in the language-for-translation classroom: corpora as learning aids. Cadernos de Tradução, 36(SPE), 14-35. https:/ / doi.org/10.5007/2175-7968.2016v36nesp1p14

Bestué, C., \& Orozco, M. (2016). Online training in legal translation. Babel, 62(3), 470-494. https:/ / doi.org/10.1075/babel.62.3.06bes 
Biel, Ł. (2011). Training translators or translation service providers? EN 15038: 2006 standard of translation services and its training implications. The Journal of Specialised Translation, 16, 61-76.

Castells, M. (2003). The Power of Identity: The Information Age: Economy, Society, and Culture Volume II. WileyBlackwell.

Chesterman, A. (2016). Memes of translation: The spread of ideas in translation theory. John Benjamins Publishing Company.

Choi, S. B., Kim, K., Ullah, S. M. E., \& Kang, S.-W. (2016). How transformational leadership facilitates innovative behavior of Korean workers. Personnel Review, 45(3), 459-479. https:/ / doi.org/10.1108/PR-03-2014-0058

Davydova, N. N., Dorozhkin, E. M., Fedorov, V. A., \& Konovalova, M. E. (2016). Research and educational network: Development management. Mathematics Education, 11(7), 2651-2665.

Deng, M. (2016). Research on the Development Condition of Functional Translation Theory and the Applications on Modern English Translation Practice. Social Science, Education and Human Science.

Dogan, S., Pringle, R., \& Mesa, J. (2016). The impacts of professional learning communities on science teachers' knowledge, practice and student learning: a review. Professional Development in Education, 42(4), 569-588. https: / / doi.org/10.1080/19415257.2015.1065899

Faber, P. (2012). A cognitive linguistics view of terminology and specialized language. Walter de Gruyter, 20.

Froeliger, N. (2013). Collection Traductologiques. Belles Lettres, 294.

Gambier, Y. (2009). Competences for professional translators, experts in multilingual and multimedia communication, 11 .

Garcia, I. (2013). Learning a language for free while translating the web. Does duolingo work? International Journal of English Linguistics, 3(1), 19. https:/ / doi.org/10.5539/ijel.v3n1p19

Gavrilenko, N. N. (2016). Sender and Recipient Special Discourse Characteristics in Teaching Translation. International Journal of Environmental and Science Education, 11(9), 2647-2658.

Göpferich, S. (2009). Towards a model of translation competence and its acquisition: the longitudinal study TransComp. In Behind the mind: Methods, models and results in translation process research (pp. 11-37).

Grosbois, M. (2012). Didactics of languages and technologies: From EAO to social networks. Paris: Presses de l'Université Paris-Sorbonne.

Gulati, S. (2008). Technology-enhanced learning in developing nations: A review. The International Review of Research in Open and Distributed Learning, 9(1).

Gümüş, V. Y. (2017). Training Translators for the Market in Turkey: What Should We Teach to Future Translators? International Journal of Comparative Literature and Translation Studies, 5(1), 1-10.

House, J. (2014). Translation quality assessment: Past and present. In Translation: A Multidisciplinary Approach (pp. 241-264). Palgrave Macmillan UK.

Kim, J. H. (2014). Foreign Language Learner's Native Culture and Translation. Information, 17(12), 6137.

Kim, S., Kim, J. W., Park, J., \& Oh, A. (2016). Elice: An online CS Education Platform to Understand How Students Learn Programming. In Proceedings of the Third (2016) ACM Conference on Learning Scale (pp. 225-228). https:/ / doi.org/10.1145/2876034.2893420

Kujamäki, P., \& Footitt, H. (2016). Military history and translation studies. Border Crossings: Translation Studies and Other Disciplines, 126, 49.

Kushnina, L. V., \& Pylaeva, E. M. (2014). Ecology of translation: contemporary trends and approaches. Perm University Herald. Russian E Foreign Philology, (2).

Martín-Blas, T., \& Serrano-Fernández, A. (2009). The role of new technologies in the learning process: Moodle as a teaching tool in Physics. Computers $\mathcal{E}$ Education, 52(1), 35-44. https:/ / doi.org/10.1016/j.compedu.2008.06.005

Martínez Melis, N., \& Hurtado Albir, A. (2001). Assessment in translation studies: Research needs. Meta: Journal Des traducteursMeta:/Translators' Journal, 46(2), 272-287. https:/ / doi.org/10.7202/003624ar

Munday, J. (2016). Introducing Translation Studies: Theories and Applications. Routledge.

O'Hagan, M. (2011). Community Translation: Translation as a social activity and its possible consequences in the advent of Web 2.0 and beyond. Linguistica Antverpiensia, New Series-Themes in Translation Studies, (10).

O'reilly, T. (2005). What Is Web 2.0.

Padilla-Zea, N., Medina, N. M., Vela, F. L. G., Paderewski, P., \& Collazos, C. A. (2017). PLAGER-VG: platform for managing educational multiplayer video games. Multimedia Tools and Applications, 1-38. 
Pérez-González, L., \& Susam-Saraeva, Ş. (2012). Non-professionals translating and interpreting: Participatory and engaged perspectives. The Translator, 18(2), 149-165. https:/ / doi.org/10.1080/13556509.2012.10799506

Remkhe, I. N., Nefedova, L. A., \& Gillespie, D. C. (2016). From Function to System: Advances in Choosing a Matrix Structure of the Translation Process. Russian Journal of Linguistics, 20(3), 230-242.

Robinson, B. J., Olvera Lobo, M. D., \& Gutiérrez-Artacho, J. (2017). The professional approach to translator training revisited.

Roh, S. Z. (2015). Structural Relationships of Adult e-Learners' Teaching Presence, Self-Efficacy toward e-Learning, and Learning Satisfaction: Focused on the Mediating Effect of Learning Presence and Learning Flow. Information, 18(6), 2759.

Shiyab, S. M. (2017). Specialized Translation: Shedding the "Non-Literary"Tag. Babel, 62(4), 686-687. https:/ / doi.org/10.1075/babel.62.4.10shi

Venuti, L. (2012). The translation studies reader. Routledge.

Wang, M., Maeda, Y., \& Takahashi, Y. (2014). Teaching Assistant System used Eye Tracking Device Based on Gaze Estimation by Neural Network and Intention Recognition by Fuzzy Inference. Information, 17, 4661-4676.

Yang, X., Guo, X., \& Yu, S. (2016). Effects of cooperative translation on Chinese EFL student levels of interest and self-efficacy in specialized English translation. Computer Assisted Language Learning, 29(3), 477-493. https:/ / doi.org/10.1080/09588221.2014.991794

Zaidan, O. F., \& Callison-Burch, C. (2011). Crowdsourcing translation: Professional quality from non-professionals. In Proceedings of the 49th Annual Meeting of the Association for Computational Linguistics: Human Language Technologies-Volume 1 (pp. 1220-1229).

\section{http://www.ejmste.com}

